\title{
IUELTAL
}

\section{Students' Perception Towards NNESTs \& NESTs' Teaching Styles: A study at State Islamic University of Ar-Raniry}

\author{
Fadhlur Rahman \\ State Islamic University of Ar-Raniry \\ e-mail:fadlurrahman@uin.ar-raniry.ac.id \\ Ella Yuzar \\ State Islamic University of Ar-Raniry \\ e-mail:ellayuzar@uin.ar-raniry.ac.id
}

\begin{abstract}
:
This paper aimed to investigate students' perspective towards their NESTs and NNESTs' teaching styles and students' preferred teaching styles. The participants for this study were collected from fifty-two English Education students of State Islamic University of Ar-Raniry who had studied with both NEST and NNEST. Data were obtained from a combination of administering questionnaire and conducting two focus group interviews. The questionnaire as the research instrument was adopted from Grasha's (1996) Teaching Style Inventory. Interviews were conducted to gain more comprehensive information regarding students' perception of NEST and NNESTs' teaching style and differences that students identified when leaning with NEST and NNEST. Using descriptive statistical analysis for the questionnaire and utilizing Miles, Huberman, and Saldaña's (2014) approach for qualitative interview analysis, the study revealed that both NEST and NNEST were perceived to have personal model teaching style and interestingly, it is also the participant preferred style. It also presented that NESTS and NNESTs have their distinctive roles in teaching-learning that are complementary to create a successful learning environment. The current research has contributed to enrich the literature work in the discussion of how students perceive NEST and NNESTs' teaching performance with implications for educational practitioners, stake holders and institutions.
\end{abstract}

Keywords: English language teaching, NEST, NNEST, students' perception, teaching styles 


\section{Introduction}

A considerable amount of debate in the literature regarding the role of native Englishspeaking teachers (NEST) and non-native English-speaking teacher (NNEST) has gained recurring prominence in the past decades. It can be observed from the research body that has been done in the field. Several studies assert that native teachers would benefit students' learning process more than local teachers and it seems to provoke most educational institutions to put high demand on them. Others believe that both types of EFL teachers have their own merits, emphasizing that NNESTs have better understanding on the students' needs and objectives. Scholars such as Cheung and Braine (2007), Tjokrokanoko and Tedjasukmana (2013) and Arvizu (2014) claim that teachers, whose English is their first language, are more favorable because the language used sounds more authentic, especially in productive skills. Further, NESTs have been regarded as "the guardian of the true language", and their authentic language output offers EFL students the standard language's model (Davies, 2006). In a more recent study, Howard (2019) who conducted a narrative research involving native English teachers in South Korea revealed that those teachers distinguished themselves as highly regarded and respected because of their "foreignness" (p. 1503) and at any point, they receive better payment despite having less workload than the non-native teachers (Gómez-Vásquez \& Guerrero Nieto, 2018).

Meanwhile, other studies have resulted that non-native English teachers are perceived not to be less proficient than their foreign colleagues but they can be entrusted to teach different aspects of language learning such as grammar, learning strategies, and classroom management (Lasagabaster \& Sierra, 2005; Diaz, 2015). Also, Walkinshaw and Oanh (2014) added that local teachers are not only competent for helping students for linguistic structure mastery but also qualified to use their bilingualism to make students feel at ease during teaching learning activity. Non-native English teacher can help low proficiency students by utilizing their first language to increase comprehension for difficult lesson. Also, it might be more effortless for the teachers to build an interactive class when they have a shared culture with the students.

Despite the eligibility of both NEST and NNEST, teachers whose English is second language are still treated with low professional prestige (Mahboob, 2010) which leads NNESTs to often see themselves as linguistically inferior compared to their professional counterpart. In addition, NNESTs frequently receive unfair treatment during the teaching-learning process (Achimbe, 2006). With such discrimination towards them, NNESTs professional self-esteem declined considerably in recent years as ELT practitioners, especially when ELT profession predominantly "conquered" by native-like ideology (Holliday, 2006). This condition, undeniably, is supported by educational stake holders and institutions who seem to emphasize teaching language merely on the productive skills and demand English to be taught by instructors from the inner circle countries. For some schools and government agencies, it is only adequate when they can afford native English teachers to attend the classes even though they have bilingual local teachers (González \& Llurda, 2016).

Drawing on previous studies, there must be an agreement that NESTs and NNESTs have different qualities. Although non-native teachers tend to be marginalized compared to their foreign colleagues who have better command on English, Yakoub (2011) alleged that students' achievement on linguistic fluency might be affected by a number of aspects, 
including the students attitude toward the learning circumstances. In other words, students' language attainment does not only rely on whether the teachers have perfectly native pronunciation or not. Therefore, it is essential to examine the issue of NEST and NNESTs' presence in the classroom, especially from the students' perspectives. Unfortunately, an investigation into students' voices on NEST and NNEST with a particular spotlight on the teachers' teaching style is still scarce. For this reason, the present study aims to investigate the students' views on their native and non-native English teachers, focusing on teaching styles and whether it is favored by the learners. By adapting Grasha's (1996) teaching style inventory and conducting a thorough focus group interview, this research is to provide a comparative investigation and display a twofold of contrasting teaching styles and strategies, with underlining both NESTs and NNESTs' primary role as educators. Hence, it is significant to note that this study is not pondering on finding who is superior in teaching English but rather providing contributive insights from students' perspective to improve the English language teaching.

\subsection{Research Questions}

This research aims to answer the following research questions:

1. What are students' perception about their Native English Speaker Teachers' teaching styles?

2. What are students' perception about their Non-native English Speaker Teachers' teaching styles?

3. What teaching styles do students prefer?

4. What differences do students identify about learning with NESTs and NNESTs?

\section{Literature Review}

\subsection{The Dichotomy of Native and Non-Native English Teacher}

To start with, Davies (2006) offers a working definition on the "nativeness" of the language. First, he describes native speaker is the one who acquire the language in the period of their childhood and speak and learn the language (English) since they were born. Second, the native speakers of the language have a capability to comprehend the language and construct idiomatic formulas of the language accurately. Third, they have a capability to differentiate between the standard forms of the language and the irregular ones without delay for cognitive process. Lastly, native speaker are the ones who competent in producing and comprehending spontaneous discourse. It means that they do not need to think or to pick the right words before speaking. Thus, we relate the definition given to the context of English language teaching/teacher, NESTs are teachers who learn and speak English as their first language. In the contrary, NNESTs are those who learn and speak English as an additional/second language. As Walkinshaw (2012) similarly emphasized, the sole 'immutable and non-developmental' differences between them is solely reflected on their childhood acquisition of the language.

However, the discordant terms of the significance of native speaker and non-native speaker teacher in ELT are still debatable and various among scholars (Butcher, 2005; Ruecker, 2011; Pennycook, 2017). In the earliest study about the significance of 'native-speakerism' in teaching language, Paikeday (as cited in Schmitz, 2013), in a discussion with Noam Chomsky, rejected the assertations about the native-speakers' supremacy because it 
ignores the educational and socio-cultural factors. However, Madrie and Canado (2004) examined NEST and NNEST by considering at skills differences, they suggested that some researchers have to put considerable effort into bringing more visibility to NNEST, arguing that the contribution of NNEST to English Education is still underestimated. Similarly, Medgyes (1992) endeavored to distinguish the difference between NEST and NNEST by claiming that "non-native speakers can never achieve a native speaker's competence" because they "can never be as creative and original" (pp. 342-343). Yet, Philipson (2012) believe that "the idolization' towards native-speaker as linguistically and socio-culturally superior is a form of colonialism.

The role of NEST has become the social prestige rather than the essential part of NEST as a teacher. There are some reasons why NESTs are assumed to have better status than NNESTs. First, it is believed that learning English directly from NEST would give better contribution for learners' second/additional language attainment, as it can be seen in some advertisements of the vacant position for English teacher in both private and public institutions as follows.

"A native-level English speaking governess (preferred) is required for a full-time position...Native-level English speaking governess, ideally with a clean British accent. The ideal age for the candidate would be 25-35." (Expat, 2019)

"We are a school in Beijing Shijingshan district and looking for a native English speaker who is white and not too old. It is very urgent because the new teachers are supposed to work from September 1st. The salary is 7000 rmb per month. The working time is 3 to 6 from Monday to Friday. Please contact me at XXX". (Source: China-Daily as cited in Mahboob, 2009)

The focus of the advertisements above is not so much on the qualities of affectionate, innovative teaching or lively engagement during teaching-learning process but rather on the "nativeness" of the teacher. In that case, qualities or credentials might be eclipsed if "the native-speakerism" specification is satisfied. Besides, in higher institutions, NEST is still considered as a better figure to handle the teaching-learning process rather than NNEST. As Walkinshaw (2012) reported, EFL/ESL institutions are trying hard to maintain their students' parent view about greater values they will get from NEST. In fact, having a NEST in the classroom does not assure a better teaching learning process.

Moreover, the distinction of NEST and NNEST may lead to the racial and discrimination issue. NEST is commonly assumed as a white, who can speak a variety of Englishes, which associated with 'the inner-circle' countries such as the UK, Australia and The United States. Most NESTs receive more opportunities in job positioning than those who are not from English (inner circle) countries, but this does not mean that all NESTs are racist and all the employee are doing discrimination. As Mahboob (2009) clarified that "the argument is not that all White ELT practitioners are racist, but rather that being White is an advantage in the field and one that does not relate to professional needs." An excerpt from a web-discussion quoted below twirls around a controversial statement. It can be seen from the quoted that an Asian-Canadian woman was not sure about the criterion given in the advertisement, so 
she wanted to confirm that it might be possible if the institution will not hire her because of the photograph she uploaded, revealing her "Asianness" more than her "Whiteness".

Woman's Post: ...but would anyone on this list be familiar with how an Asian-American or Asian-Canadian or ANY female with obviously Asian ethnic blood (but who grew up in the West) would be treated in the Middle East? Would I be at a disadvantage in the hiring process (since we're required to send photos) because I don't have the Western "look" despite my Western credentials and upbringing?

Response: As for getting a teaching job, well let me put it like this: it would be perfectly normal for a white Brit with mediocre experience and qualifications to be preferred over a non-white native-speaker of English with excellent qualifications and extensive experience. Sad, but unfortunately very true. Sadder still: it's normally Westerners making these decisions NOT locals! (Source: ESL-Cafe as cited in Mahboob, 2009)

The conversation above clearly showed that being a native speaker give a great influence to hired in a recruitment decision. The 'nativeness' issue is fed by the notion that native speakers are perfect in each element of the language, this might true, but not in every single case, especially in the context of teaching. In the ELT classroom, there are many hurdles to overcome, you just cannot stand there and show off your 'nativeness' of the language, it is much more than that. As Achimbe (2006) asserted, ELT is not a regular field to show the nativeness, but rather a field of profession that requires competence and training. In short, for such a long time, EFL teaching in worldwide contexts have employed typical phases in educational discourse, NEST is regarded as cultural-lingua intermediaries of English as their idealized version of the language (Howard, 2019). Meanwhile, NNEST trajectories are transient by nature and they are often regarded as unexperienced and unqualified (Ruecker and Ives, 2015). Nevertheless, it is argued that instead of the 'nativeness' of the language, teachers' teaching styles in the classroom is the most prominent manifestation and indicator of how educational system is succeeding (Singh, Singh \& Gautam, 2009).

\subsection{NEST and NNEST in ELT}

There are numerous interesting studies that have enriched the discussions regarding the role of NEST and NNESTs' teaching styles in English language teaching, especially from outer and expanding circle countries (Ma (2012); Chun, 2014; Howard, 2019). In China, Rao (2010) reported that 36 students of Jiangxi Normal University viewed their native English teachers as two-edged in which they acquainted a constructive personality exhibited by NESTs since they have cultural familiarity with the language learned that can attract students' interests, language authenticity in pronunciation, and brand-new methodology which could make the class more lively. The students seemed to benefit for these NESTs' qualification as they might not receive it from their local teachers. On the other hand, the result of the study also shows that the main problems encountered in NESTs' classes are conflict between the teaching styles and learning strategies, and unfamiliarity with the educational system, and the insensitivity to students' morphological and syntactic problems. In a similar vein, Walkinshaw and Oanh (2014), whose study involved students from Japan and Vietnam, affirm that NESTs are best at teaching pronunciation and showing 
how to use English correctly and contextually. In contrast, non-native teacher can teach grammatical structure and accuracy much better than the NESTs and they have the advantage of being able to address students' first language whenever it is necessary. Interestingly, even though the students recognize the local teachers' flawed English pronunciation, they still consider it acceptable as it is easier to understand.

In the Indonesian context, Tjokrokanoko and Tedjasukmana (2013) found that both NESTs and NNESTs have equal capability in almost all categories, except cultural context of the language. Yet, the result confirmed that NEST have no clue about students' individual needs. In a more recent study, Novianti (2018) surveyed twenty-five undergraduate students in an Indonesian university by delivering questionnaire to collect students' voice on NEST and NNESTs' teaching performance. She found a compelling result that show students' positive attitude towards both native and non-native teachers despite their strengths and weaknesses. As a matter of fact, the participants do not bother whether their teachers are from west countries or not as long as they can perform quality teaching competence to help them increase the students' proficiency.

\subsection{Description of Grasha's (1996) Teaching Styles}

Teaching style is a significant issue in ELT. According to Shafie and Alias (2007), a mismatch between teaching styles and students' learning strategies emerge to be simultaneous with students' low interest towards the subject. In a similar vein, Lage et al. (2000, p.30) asserted that students may preserve and gain extra knowledge if their learning strategies equivalents with the teaching style. In that case, teachers must be flexible during the instructional process or students will be demotivated. As more unfortunate potential consequences, students will perhaps incline to be uninterested and tired toward the subject, do poorly on the test, and give up. Therefore, to avoid the failure and to correspond students' learning desires, teachers, either NESTs or NNESTs, must apply the appropriate teaching style in the classroom. The teaching style is viewed as a selective pattern of beliefs and needs that teachers may demonstrate and operate during the classroom process. In Grasha's (1996) seminal work, there are at least several prototypes that describe the qualities of university lecturer. It includes five teaching styles that distinctly illustrate the occupancy of instructional strategies i.e. formal authority, expert, facilitator, delegator, and personal model teaching styles (Grasha and Yangarber-Hicks, 2000).

Formal authority style of teaching is teacher- centered and the focus is on the content and materials (Grasha, 1996). Teachers who employ this prototype, mostly apprehensive in controlling the flow of the content than performing a direct communication. Further, they tend to more focused in presenting feedback (both positive and negative). In formal authority style, teacher is most likely highlighting the class rules, learning goals, and tolerable attitudes in doing things in the classroom rather than building and having connections with students. The drawback of this teaching style is that it may become a fixed patterned and standardized style, not a flexible one.

Expert style which is also known as the "sage on the stage" model, requiring teachers to have knowledge and proficiency that the students need (Grasha, 1996). He further emphasized that since teacher seeks to maintain their status as an expert for the students, transferring knowledge are certainly the main focus, so students may have sufficient preparation for their courses. The expert teachers are opposed to the formal authority style 
teachers, in that they would barely be willing to establish relationships with their students. They would rather to maintain the barrier and do not feel that building relationships with students is necessary for their knowledge acquisition. The benefits of using this style may enforce students to become more lenient to obtain skill, knowledge and values being given by such teachers. However, it might not suit for below average students as they could become demotivated or frustrated.

Facilitator teaching styles emphasizes on the nature of teacher-student interactions (Grasha, 1996). He asserted that teachers may guide and direct students in several ways. For instance, teacher may ask students engaging questions, provide alternatives to students' responds, and encourage them to make informed choices. This type of teacher usually attempts to create activities in which student feel more responsible for their own learning, for example, group learning activities which require active learning, collaborative learning with pairs, and problem-solving tasks. It has been 'facilitator' teachers' goal to expand students' capacity for independent, initiative and responsible learning.

Delegator teaching style has a primary goal to let the students' capacity function autonomously (Grasha, 1996). One of the activities implemented in the class is the freedom to choose a project and then students may choose the design and the instruction completely by following the required activities. For example, student may work independently or in groups. Equally important, this style requires students to be able to maintain a constant motivation and focus on the projects. Also, it requires interpersonal skills in order to work effectively in a group. This teaching style addresses that teacher may solely function as a consultant or a resource to provides a required direction based on students' appeal. It is argued that this method helps the students to become more selfdirected and autonomous learners (Grasha, 1996). Nonetheless, it can also be harmful for those students who cannot work independently and those who lack of comprehension on the subject could be more marginalized.

Personal model predominantly focuses on 'teaching by example' (Grasha, 1996). Teachers are seen as role models for students, and they should demonstrate the skills required to achieve the aim of the course. Thus, this teaching style is very much oriented with demonstrating, helping students to learn new skills and encouraging them to participate in the learning process. Moreover, teacher must help improve students' skills and apply those skills in real-life situation. Despite the fact that this style is still teacher-centered, students' participation in the class is most likely to be addressed and appreciated. Teachers are expected to have responsibility in questioning students' opinion during the lesson and find out whether they need assistance to complete the task or not.

\section{Research Methodology}

\subsection{Participants}

Fifty-two respondents from Islamic State University of Ar-Raniry, Indonesia, participated in this study. There were thirty-four female and twenty male undergraduate students who were undertaking third year of their study. Before administering the questionnaire, all participants were assured that they all were active students who had experienced and enrolled in both NESTs and NNESTs' classes. Later, 11 out of 52 respondents were randomly 
chosen to do a focus group interview. For ethical consideration, all parties involved were informed about the purpose of the research and their identities remained anonymous.

\subsection{Instruments}

Data for the present study were collected in two phases i.e. by administering questionnaire and conducting 2 focus group interviews. The items in the questionnaire were adapted from Anthony Grasha's Inventory (1996) "Teaching with Style" (pp. 161-164). Questionnaires would result in five types of teaching style, which are formal authority, expert style, facilitator, delegator, and personal model. The answers were given in five-point Likert scale ranging from 1- Strongly disagree, 2- Somewhat disagree, 3- Neither disagree or agree, 4Somewhat agree, and 5- Strongly agree. The questionnaires were distributed to the participants who were divided into three classes. The participants were given some explanation regarding the purposes of the conducted survey before the questionnaires were given.

The second evidence for the study was collected from focus group interviews. This qualitative data collection tool was employed for the purpose of creating dynamic and interactive discussion sessions in which the participants could share and compare opinions regarding their perception (Morgan, 2018). The interviews were divided into two focus group interviews. The first consisted of five students and the second one consisted of six students. The interview sessions were audio taped. Later, the recordings were transcribed and coded to analyze information about students' perception towards their Non-native English Speaker Teachers' teaching styles and those of Native English Speaker Teachers' teaching styles.

\subsection{Data Analysis Procedures}

The results of the Teaching Style Inventory were analyzed using descriptive data analysis to observe the average score of the Likert-Scale. The analysis was divided into three groups i.e. students' perception of NEST teaching style, students' perception of NNEST teaching style and students' preferred teaching style. Each group has five types of teaching styles. The scores of teaching styles from each group were summed and compared to the scores belong to the other group. The purposes are to determine if there was a statistical difference between groups in each teaching styles. The highest score of the five types of teaching styles in each group represented the students' perception of their NESTs and NNESTs' teaching style. For the interview data, we interviewed the participants and took notes simultaneously. Following Miles, Huberman, and Saldaña (2014), the result of the group interview were applied on the three-phase analysis namely, condensation in which the data is selected and simplified based on analytic choices, display where the extract is organized in order to retrieve essential information and logical conclusion, and finally, verifying conclusion in which the pattern can interpret participants' perception and preferences about teaching styles. 


\section{Findings}

\subsection{Research Question 1: What is students' perception about their Native English Speaker Teachers' teaching styles?}

Table 1: Students' perception towards their NEST's teaching styles.

\begin{tabular}{lccc}
\hline Type of Teaching Style & $\mathbf{N}$ & Mean & Std. Deviation \\
\hline Expert & 52 & 3.67 & 0.59 \\
Formal Authority & 52 & 3.45 & 0.64 \\
Personal Model & 52 & 4.24 & 0.62 \\
Facilitator & 52 & 3.61 & 0.68 \\
Delegator & 52 & 3.13 & 0.61 \\
Valid N (listwise) & 52 & & \\
\hline
\end{tabular}

Table 1 displays the results of students' perspective towards the teaching styles of their NESTs in the English language classroom. However, based on the mean score, the most dominant teaching style perceived by the students in their English class was Personal Style (mean $=4.24$, SD $=0.62$ ), while the least dominant teaching style was Delegator Style (mean $=3.13 \mathrm{SD}=0.61)$.

\subsection{Research Question 2: What are students' perception about their Non-native English Speaker Teachers' teaching styles?}

Table 2: Students' perception towards their NNEST's teaching styles.

\begin{tabular}{lccc}
\hline Type of Teaching Style & $\mathbf{N}$ & Mean & Std. Deviation \\
\hline Expert & 52 & 3.67 & 0.52 \\
Formal Authority & 52 & 3.28 & 0.63 \\
Personal Model & 52 & 4.15 & 0.52 \\
Facilitator & 52 & 3.34 & 0.59 \\
Delegator & 52 & 2.75 & 0.58 \\
Valid N (listwise) & 52 & & \\
\hline
\end{tabular}

The table above presents that the most dominant teaching style perceived by the students in their English class was Personal Model Style (mean $=4.15, \mathrm{SD}=0.52$ ), while the least dominant teaching style was Delegator Style (mean $=2.75 \mathrm{SD}=0.58$ ). As for expert, formal authority and facilitator, the mean scores are almost equally spread which means some students view their NNEST to have those styles of teaching performance.

\subsection{Research Question 3: What teaching styles do the students prefer?}

Table 3: Students' preferred teaching styles

\begin{tabular}{llcc}
\hline Type of Teaching Style & $\mathbf{N}$ & Mean & Std. Deviation \\
\hline Expert & 52 & 3.46 & 0.75 \\
Formal Authority & 52 & 3.20 & 0.80 \\
Personal Model & 52 & 4.53 & 0.33 \\
Facilitator & 52 & 3.71 & 1.01 \\
Delegator & 52 & 2.98 & 0.82
\end{tabular}


Fadhlur Rahman \& Ella Yuzar

\begin{tabular}{llcc}
\hline Type of Teaching Style & N & Mean & Std. Deviation \\
\hline Expert & 52 & 3.46 & 0.75 \\
Formal Authority & 52 & 3.20 & 0.80 \\
Personal Model & 52 & 4.53 & 0.33 \\
Facilitator & 52 & 3.71 & 1.01 \\
Delegator & 52 & 2.98 & 0.82 \\
Valid N (listwise) & 52 & & \\
\hline
\end{tabular}

Table 3 informs the data on students' preference for their lecturers' teaching styles in the English language classroom. Based on the mean score, it can be seen that students preferred their lecturers to use more personal model teaching style (mean $=4.53, \mathrm{SD}=0.33$ ) and Facilitator Style (mean $=3.71, \mathrm{SD}=1.01$ ) compared to other teaching styles. The most preferred teaching style was personal style, while the least favorite was delegator style. this suggests that there was a clear preference for students to a teacher-centered approach as students demand their lecturers to assist them in learning new skills, as well as aid and guide them in developing or applying the required skills in real world problems.

\subsection{Research Question 4: What differences do students identify about learning with NESTs and NNESTs}

Teachers or lecturers apply different methods and activities. Some lecturers are comfortable standing in front of the classroom and giving a long monolog during the instructional process; others would take the students outside the classroom to find a different learning atmosphere. In English Education department of State Islamic University of Ar-Raniry, either NEST or NNEST has its own teaching methods and activities. As Student 2 responded, "We even had some outdoor activities which is different from NNEST." This asserts that NEST most likely to use physical response methods and outside classroom activities more often than NNESTs.

Regarding the content of the course, NEST and NNESTs differ in designing the teachinglearning content. Even though both of them have the same syllabus, the past learning experience of both teachers will cause differences in arranging the teaching content or the materials provided. When NESTs teach in English classrooms, they often insert the information of their culture in their teaching materials, which for the students, it may seem fascinating. They also design innovative teaching materials by themselves. As a student 4 said:

"NESTs use more media in teaching with such colourful markers, flashcards, teaching vowels, they also often bring authentic material such as newspaper or magazine that he brought from his home country, even a poster and commercial adverts, etc." (Student 4)

Nevertheless, NESTs have missed the objective of the course and failed to stick on the lesson plan. As students also stated:

"It was a speaking class, but my NEST tends to focus on phonology, and he took a lot of time to explain that" (Student 9) 
"Sometimes NEST does not follow the aim of the course, and most of the time stuck with one thing and forgot to teach other essential items, that's not very good." (Student 2)

In contrast, NNESTs tend to follow and focus on the language learning objective. NNESTs also put more efforts and attention in designing linguistics-context materials.

Students perceived no problem with the accent. They are more interested in learning new phrases and idioms, so they do not have a problem with their NNESTs' accent and pronunciation. As student 8 and 7 illustrated:

"He (NEST) teaches us many new vocabularies and phrases that we do not find it on the dictionary before, and it is nice to hear directly from an American accent." (Student 8)

"In my opinion, my NNEST also has a very nice accent even though she doesn't learn and speak English as her first language. But, since she had studied in an English-speaking country for years, the pronunciation is almost the same." (Student 7)

Hence, it can be concluded that the perception of NEST's accent as the ideal English accent is no longer validated. Moreover, when the students were asked to choose which they prefer for the next course, seven out of eleven students we interviewed $(64 \%)$ preferred NNEST and 4 out of eleven students (36\%) preferred NEST to teach in their class. The students' preference for NNEST because of the discernment was echoed by student 6 :

"I prefer NNEST since they understand what I need more than NEST. Let's say they graduated from this English Education department. It surely makes them know more what I have to do with a problem I regularly faced when learning English, and they show me the way how to solve it." (Student 6)

Lastly, students do not view both NEST and NNEST as different personalities. Both NESTs and NNEST have Personal Model teaching style. Both of them were also individually appreciated by students. Yet, NEST and NNEST have their own capabilities to fulfil the students' needs to achieve satisfactory learning outcomes.

\section{Discussion}

The present study has attempted to investigate students' perception about their NEST and NNEST teaching style and their views toward both type of English instructors. Using Grasha's (1996) teaching styles inventory, the result of the survey shows that most students viewed NESTs to have personal model teaching style. It has been widely known that NESTs have a tendency to focus on encouraging the students to participate in the learning process (Rao, 2010; Howard, 2019) which is an indication of Personal Model teaching style. The students also revealed that NESTs regularly attract students' recognition by demonstrating how to pronounce the vocabulary correctly. They give students a task or project to be presented in front of the classroom, and the main aim of this task was to improve students' speaking skills. Also, NESTs occasionally tell a story about their experiences, cultural and traditional values from their home countries. This is congruence to Carless's (2006) assertions that NESTs tend to facilitate students to communicate through English-only approach rather than a reversion to students' first language, this can be used as the main 
resource skill and may play a part in enhancing student motivation to learn and to use English.

The analysis of questionnaire also resulted in that most students perceive NNEST to adopt personal model style. This outcome is supported by the students' confession, noticing that NNESTs in the English department have been working hard to prepare the materials and lesson plan so that the students will be understand the lesson given. Equally important, based on students' view, NNESTs are accessible for asking questions and for initiating discussion if there were unclear instructions or information. After all, most students considered that NNESTs have similar teaching styles to NESTs. This result, surprisingly, repudiates Maum's claim (2004) about NNESTs as he claimed that NESTs are seen as the ideal teachers, while NNESTs are viewed as less instructional qualified and less linguistically competent than NESTs. Furthermore, despite the fact that NNEST is still teacher-centered, NNESTs always encourage students' participation during teaching-learning process. NNESTs also expect students to seek assistance if they do not understand the lesson (Walkinshaw \& Oanh, 2014).

The result of focus group interview has also unveiled several interesting points regarding the students' attitude toward their NEST and NNEST. Following Rao (2010) and Tjokrokanoko and Tedjasukmana (2013), the present study affirms the characteristics of NESTs who are able to apply an engaging teaching methodology that can attract students' attention. This classroom activity is also supplemented with sessions in which foreign teachers like to share cultural stories and values from their home countries. It is of paramount importance for the students to know about culture of the language they are learning. However, one of the downsides of assigning NEST in foreign language classroom is that they tend to hinder the syllabus and learning objectives set by the faculty. On the contrary, NNESTs seem to be more organized with classroom management and accomplished in teacher grammar and syntactical forms. This is coordinated with $\mathrm{Ma}$ (2011). In terms of teachers' pronunciation when speaking English in the classroom, the participants do not perceive it as a significant value from which they prefer NEST over NNESTs. In consistency with Walkinshaw and Oanh (2014), most students consider local teachers' English pronunciation to be adequate and easier to comprehend as occasionally they can codeswitch to learners' first language. This has been reported by Gómez-Vásquez and Guerrero Nieto (2018) that non-native teachers could speak English with a native-like pronunciation because some of them graduated or received training certificates from overseas universities. Finally, it is also evidenced by the result of the study that, at any point, EFL students would be more preferable to be taught by teachers who shared the same cultural background with the learners as they can understand the students' need more than foreign teachers.

In sum, the current research has contributed to enrich the literature work in the discussion of how students perceive NEST and NNESTs' teaching performance. The finding has important implications for at least two major respects. It informs language teachers that it is strongly suggested to consider students' preferences regarding the teaching style employed in the classroom. Additionally, it might advocate the previous studies whose results indicate that there should not be any disparities between NEST and NNEST as both have their own qualities and inform educational stakeholders and institutions to prioritize the students' demands rather than the prestige of hiring native teachers. Nevertheless, 
regarding the limitations in this study, more research should be conducted in this field that involve a larger number of participants and compare the perception based on students' gender. Future investigation is also important to include the teachers' voices in order to validate the results.

\section{Conclusion}

There are several points that could be compiled. First, even though the results of the research showed that both NEST and NNESTs' teaching styles are similarly perceived by most of the students, which is personal model teaching style. Next, different teaching behavior between NEST and NNEST could be derived from students' perception. One of which is that NEST are more able to create a lively classroom activities compared to the local teachers, but on the other hand, NNESTs could compromise more to what the students' needs as they had similar cultural background with the students.

\section{References}

Achimbe, E. (2006). The Native Speaker Fever In English Language Teaching (ELT): Pitting Pedagogical Competence Against Historical Origin, Linguistik Online, 26, 3-14.

Arvizu, M. N. G. (2014). Students' Beliefs And Expectations Of Native And Non-Native English Teachers. MEXTESOL Journal, 38(3), 1-15. Available At: http://www.mextesol.net.

Butcher, C. (2005). The Case Against The Native Speaker. English Today, 21(2), 13-24.

Carless, D. R. (2006). Good Practices In Team Teaching In Japan, South Korea And Hong Kong. System: An International Journal Of Educational Technology And Applied Linguistics 34, 350-351.

Chun, S., Y. (2014). EFL Learners' Beliefs About Native And Non-Native English-Speaking Teachers: Perceived Strengths, Weaknesses, And Preferences. Journal Of Multilingual And Multicultural Development, 35(6), 563-579. doi: 10.1080/01434632.2014.889141

Cheung, Y. L., \& Braine, G. (2007). The Attitudes Of University Students Onwards NonNative Speakers' English Teachers In Hong Kong. RELC Journal, 38(3), 257-277.

Davies, A. (2006). The Native Speaker In Applied Linguistics. In Davies, A., And C. Elder (Eds.), The Handbook Of Applied Linguistics (Pp. 431-450). Malden: Blackwell Publishing.

Díaz, N. R. (2015). Students' Preferences Regarding Native And Non-Native Teachers Of English At A University In The French Brittany. Procedia-Social And Behavioral Sciences, 173, 93-97.

Expat. (2019, September 20). English Teacher Native Speaker. https://www.expat.com/en/jobs/europe/russia/moscow/115-language-teacher/490658english-teacher-native-speaker.html

Grasha, A.F. (1996). Teaching With Style: A Practical Guide To Enhancing Learning By Understanding Teaching And Learning Styles. Pittsburgh, PA: Alliance Publishers.

Grasha, A. F., And Yangarber-Hicks, N. (2000). Integrating Teaching Styles And Learning Styles With Instructional Technology. College Teaching, 48(1), 2-11.

Gómez-Vásquez, L. Y., \& Guerrero Nieto, C. H. (2018). Non-Native English-Speaking Teachers' Subjectivities And Colombian Language Policies: A Narrative Study. Profile Issues In Teachers Professional Development, 20(2), 51-64. 
González, A., \& Llurda, E. (2016). Bilingualism And Globalisation In Latin America: Fertile Ground For Native-Speakerism. In F. Copland, S. Garton, \& S. Mann (Eds.), Lets And Nests: Voices, Views And Vignettes (Pp. 90-109). London, Uk: British Council.

Holliday, A. (2006). Native-Speakerism. ELT Journal, 6o(4), 385-387.

Howard, N. (2019). Constructing Professional Identities: Native English-Speaking Teachers In South Korea. The Qualitative Report, 24(7), 1478-1510. Retrieved From https://nsuworks.nova.edu/tqr/vol24/iss7/1

Lage, M. J., Platt, G. J., \& Treglia, M. (2000). Inverting The Classroom: A Gateway To Creating An Inclusive Learning Environment. The Journal Of Economic Education, 31(1), 30-43.

Lasagabaster, D., \& Sierra, J., M. (2005). What Do Students Think About The Pros And Cons Of Having A Native Speaker Teacher. In Llurda, E. (Ed.), Non-Native Language Teachers: Perceptions, Challenges And Contributions To The Profession (Pp. 217-241), New York: Springer.

Ma, L. P. F. (2012). Strengths And Weaknesses Of NESTS And Nnests: Perceptions Of Nnests In Hong Kong. Linguistics And Education, 23(1), 1-15.

Madrie, D. \& Canado, M. P. (2004) Teacher And Student Preferences Of Native And Nonnative Foreign Language Teachers. Porta Linguarum, 2, 125-138.

Mahboob, A. (2009). Racism In The English Language Teaching Industry. Studies In Applied Linguistics And Language Learning, 27-37.

Mahboob, A. (Ed.). (2010). The NNEST Lens: Non-Native English Speakers In TESOL. Cambridge Scholars Publishing.

Maum, R. (2004). A Comparison Of Native-And Non-Native English-Speaking Teachers' Beliefs About Teaching English As A Second Language To Adult English Language Learners. Ph.D. Dissertation. University Of Louisville Adviser.

Medgyes, P. (1992). Native Or Non-Native: Who's Worth More? ELT Journal, 46, 340-349. Doi:10.1093/Elt/46.4.340.

Miles, M. B., Huberman, A. M., \& Saldaña, J. (2014). Qualitative Data Analysis: A Methods Sourcebook. 3rd. Ed: Thousand Oaks, CA: Sage.

Morgan, D. L. (2018). Basic And Advanced Focus Groups. SAGE Publications.

Novianti, A. (2018). Native Versus Non-Native English Speaking Teachers: An Insight Into Indonesian Students' Voices. Jurnal Pendididkan Bahasa Dan Sastra, 18(1), 44-57.Doi: 10.17509/Bs_Jpbsp. V18i1.12145

Pennycook, A. (2017). The Cultural Politics Of English As An International Language. London, UK: Routledge.

Phillipson, R. (2012). Linguistic Imperialism. Oxford, England: Oxford University Press.

Rao, Z. (2010). Chinese Students' Perceptions Of Native English-Speaking Teachers In EFL Teaching. Journal Of Multilingual And Multicultural Development. 31(1), 55-68.

Ruecker, T. (2011). Challenging The Native And Non-Native English Speaker Hierarchy In ELT: New Directions From Race Theory. Critical Inquiry In Language Studies, 8(4), 400422.

Ruecker, T., \& Ives, L. (2015). White Native English Speakers Needed: The Rhetorical Construction Of Privilege In Online Teacher Recruitment Spaces. TESOL Quarterly, 49(4), 733-756.

Schmitz, J. R. (2013). The Native Speaker And Nonnative Speaker Debate: What Are The Issues And What Are The Outcomes? Calidoscópio, 11(2). 
Shafie, M. S., \& Alias, M. (2007). Hubungan Di Antara Gaya Pembelajaran, Gaya Pengajaran Dan Minat Terhadap Subjek Kejuruteraan. Jurnal Sains Sosial, 4(1), 19-40.

Singh, S., Singh, S., \& Gautam, S. (2009). Teaching Styles And Approaches: Medical Students Perceptions Of Animation-Based Lectures As A Pedagogical Innovation. Pakistan Journal Of Physiology, 5(1).

Tjokrokanoko, A., \& Tedjasuksmana, H. (2013). EFL Secondary Students' Perceptions On Native And Nonnative English-Speaking Teachers. Beyond Words, 1(1), 138-169.

Walkinshaw, I. (2012) Native- And Non-Native Speaking English Teachers In Vietnam: Weighing The Benefits. The Electronic Journal For English As A Second Language. 16(3), 10-12.

Walkinshaw, I., \& Oanh, D. H. (2014). Native And Non-Native English Language Teachers: Student Perceptions In Vietnam And Japan. Sage Open, 4(2), 2158244014534451.

Yakoub, E. (2011). Attitudes Of Jordanian Graduate Students And Teachers Towards Native And Non-Native English Language Teachers. Unpublished MA Thesis, Mno.Dle East University, Jordan. 